\title{
A Study of the Centuries-Long Reliance on Local Ceramics in Jerash Through Full Quantification and Simulation
}

\section{Iza Romanowska, et al. [full author details at the end of the article]}

Accepted: 20 January 2021/Published online: 15 February 2021

(C) The Author(s) 2021

\begin{abstract}
The Danish-German Jerash Northwest Quarter Project revealed a robust and striking pattern of the extreme dominance $(>99 \%)$ of locally produced ceramics over six centuries and across different depositional contexts (in total over half a million pottery sherds). The archaeology of Jerash points towards an exceptional degree of selfsufficiency in craft products: why? The project team implemented a full quantification approach during excavation, manually and digitally recording and counting all pottery and other classes of artefacts. This enabled a full analysis of trends in production and use of ceramics throughout the archaeologically documented history of Jerash and revealed the unexpected pattern of the extreme dominance of local pottery. Archaeologists formulated a set of hypotheses to explain this pattern, and we developed an agent-based model of simple customer preference driving product distribution to evaluate several explanatory factors and their potential interactions. Our simulation results reveal that preference for locally produced ceramics at Jerash might be a plausible theory, but only if its intrinsic value was considered rather high in comparison to other goods, or if it was preferred by a majority of the population, and there was a tendency to follow this majority preference (or a combination of these factors). Here, we present a complete research pipeline of a full quantification of ceramics, analysis and modelling applicable at any archaeological site. We argue that transparent methods are necessary at all stages of an archaeological project: not only for data collection, management and analysis but also in theory development and testing. By focusing on a common archaeological material and by leveraging a range of widely available computational tools, we are able to better understand local and intra-regional distribution patterns of craft products in Jerash and in the ancient eastern Mediterranean.
\end{abstract}

Keywords Ceramics · Eastern Mediterranean · Roman archaeology · Data analysis · Open science $\cdot$ Agent-based modelling

\section{Introduction}

The full quantification of ceramics from the Northwest Quarter in Jerash, ancient Gerasa (Jordan) (Fig. 1) reveals a striking pattern: over 625,000 sherds across diverse 


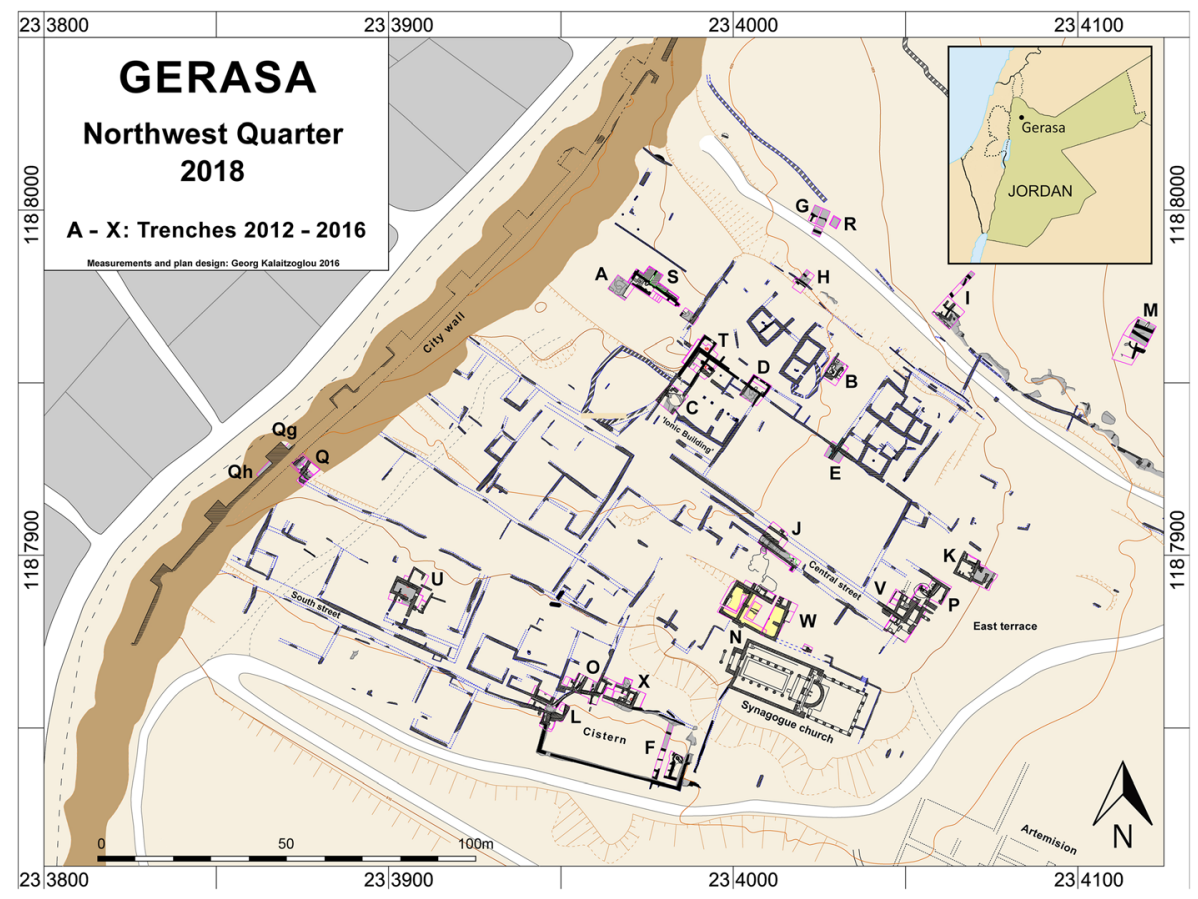

Fig. 1 The Jerash Northwest Quarter excavations with trench letters (๑) Danish-German Jerash Northwest Quarter Project)

contexts show the dominance ( $>99 \%$ ) of locally produced tableware, coarse ware and cooking ware. This pattern is evidenced from at least as early as the second century AD and throughout the history of the city as it was consecutively part of the Roman, Byzantine and Umayyad empires, until the mid-eighth century AD when it was hit by an earthquake leading to an occupation hiatus at the Northwest Quarter. During all that time, imported ceramics from the region or other parts of the world are rare. The local ceramics cover all functional categories required for daily use but are limited in their typological diversity. Moreover, a reliance on local production is demonstrated in the excavated glass artefacts as well as metal objects (Barfod et al., 2018; Orfanou et al., 2020), architecture and sarcophagi produced in the local limestone, as well as the generally low amount of imported amphorae. The archaeology of Jerash points towards an exceptional degree of self-sufficiency in craft products: why?

Jerash, is a mid-sized urban centre in the Roman province of Syria, and later, Arabia. It was part of the Decapolis league of cities - the only nominally ten most prominent cities of the Roman Southern Levant brought together by their shared language, cultural and political similarity (Lichtenberger 2003; Raja 2012, 137-189). The monumental architecture, imperial visits and the size of the urban area suggest that Jerash constituted an important regional centre in terms of the administrative, cultural, religious and economic life of the area (Lichtenberger and Raja 2020a; Lichtenberger and Raja 2020b). Its location in the region's interior, fairly far from the coast and not directly on the Via Traiana Nova, meant that long-distance trade through the main arteries of the region would not go through Jerash but a network of secondary roads provided connectivity instead. Jerash was a well-known local ceramics production centre, and 
the distinct so-called Jerash bowls and lamps are regularly found on sites across the region (Uscatescu 2019; Bes et al., 2020).

The peculiar ceramic data pattern could be explained by a range of theories, including Jerash's limited integration in ancient transport systems and distance from the coast, and the great local conditions for pottery production. Among credible explanations, we also need to incorporate another element: a simple preference for the local ceramic products over other types of ceramics. Testing such explanatory efforts faces challenges: hardly any quantitative information of ceramic assemblages at sites in the wider region has been published and our current state of knowledge about the morphological and geochemical signatures of the local Jerash products is limited.

Here, we show how a data-driven research strategy can leverage the potential of a common archaeological material, enabling the evaluation of complex social theories about product preference and a better understanding of intra-regional distribution patterns of craft products in the eastern Mediterranean even in the face of these limitations. Although it is not possible to fully reconstruct the social and economic history of the region on the basis of pottery stemming from an individual site, the relevance of this comprehensive approach lies in the development of a research pipeline which takes the most common archaeological material group and uses it to examine specific mechanisms of product preference. This pipeline is generalisable enough to facilitate future explanatory efforts at Jerash but also at similar projects at other sites in the region, and as such, it will further future research agendas and approaches.

In this paper, a statistical description of the ceramic data pattern we aim to understand is followed by a discussion of the context of ceramic production and distribution in Jerash and its wider region. Theories of individuals' preferences for the local Jerash products are formulated, and we explore their long-term implications by comparing agent-based simulation with the ceramic data pattern to identify plausible theories of product preference.

\section{Ceramic Data Pattern}

Seven hundred fifty-eight thousand ceramic sherds (includes over 100,000 topsoil finds) from all trenches excavated between 2012 and 2016 by the Danish-German Jerash Northwest Quarter Project were documented (Lichtenberger and Raja 2019; Fig. 1). This strategy of full quantification was adopted in light of the need to better understand local and regional ceramic production in the Decapolis region and the knowledge that any other collection strategy would favour fine tableware and imported pottery counts (which can be used for identifying long-distance contacts and serve as dating evidence). Instead, full quantification allows for an analysis of all ceramic spatial origins (local, regional, imported), functional categories, proportions across diverse contexts and chronological trends in combination with other dating evidence (Romanowska et al., 2021). The material is divided into three categories of local, regional and imported ceramics: local — made in the urban-suburban area (to the best of our knowledge); regional-from the region around Jerash including the Decapolis (which would make these 'regional imports', but from fairly close by); importeddefinable imports from beyond the 'regional' (such as Roman fine wares, amphorae, Nabataean pottery). However, we must assume that the secure identification of regional 
ceramics is problematic given the limited knowledge of pottery produced in the region, although we do not expect the general trend in the collected ceramics to change significantly in light of this bias. Here, we focus on comparing the proportions between local and imported ceramics, which we consider particularly reliable. All data used and the Python script (in Jupyter Notebook) to perform the data analysis are freely available online (Lichtenberger and Raja 2020a, 2020b; Romanowska 2020). For more details on the data analysis and a description of other data patterns not studied in the current paper, please see Romanowska et al., (2021).

The exploratory data analysis (EDA) revealed one general trend: for a period of more than six centuries, over $99.31 \%$ of all ceramics was locally produced across all ceramic functional categories. When we add up all excavated ceramics, $0.49 \%$ is imported and $0.20 \%$ is regional (Fig. 2, left). We can explore this pattern in more detail by focusing on particular trenches and functional categories and by exploring dated contexts.

Some differences can be identified across the 24 excavated trenches. Trenches K, P and $\mathrm{V}$ offer in situ contexts closed by the earthquake of AD 749, providing snapshots of particular household situations of the late Umayyad period in the Northwest Quarter (Fig. 2 middle). Proportions of imports differ from nearly none $(0.32 \%)$ in trench K (a house that was in use and inhabited at the time of the earthquake; Lichtenberger and Raja 2016) to $11.30 \%$ in trench V (a house undergoing restoration at the time of the earthquake; Kalaitzoglou et al., forthcoming; for trench P, see Lichtenberger \& Raja, 2017). Further evidence is offered by trenches B, J and N, ancient olive oil presses that, after becoming disused, were filled in over a short period with huge amounts of debris including ceramics (i.e. secondary fills). The amount of imports for all three is extremely low $(0.02 \%$ in $\mathrm{B} ; 0.50 \%$ in $\mathrm{J} ; 0.60 \%$ in N; Fig. 2 right; Kalaitzoglou et al., 2013). These six trenches confirm the general picture emerging from all 24 trenches: that imports were rare with some diversity (e.g. trenches $\mathrm{P}$ and $\mathrm{V})$.

The same trend can be observed across functional categories. The vast majority of excavated ceramics is tableware $(79 \% ; n=491093)$, followed by coarse wares and

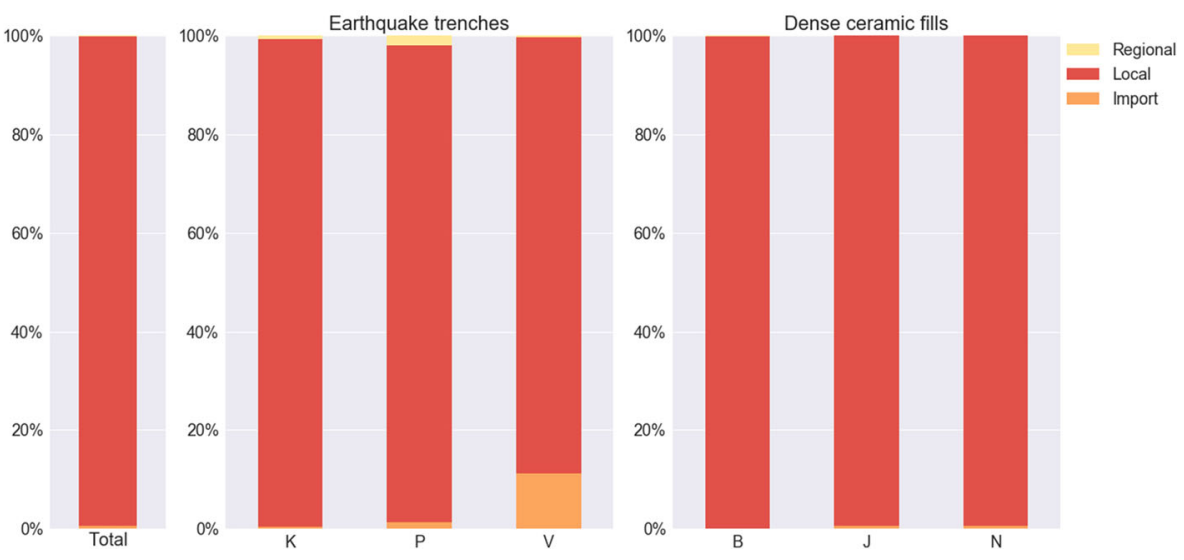

Fig. 2 The proportion of locally produced, regional and imported pottery for (left: 'total') all excavated ceramics ( $n=625,063$; excludes 133,584 topsoil entries), (middle) three securely dated trenches closed by the earthquake event of $\mathrm{AD} 749(\mathrm{~K} n=10006 ; \mathrm{P} n=2184 ; \mathrm{V} n=10614)$ and (right) three trenches consisting of ancient olive oil press installations filled in with ceramics (B $n=58751 ; \mathrm{J} n=144390 ; \mathrm{N} n=71$ 555) 
cooking wares, all of which are dominated by local pottery (>99\%) (Fig. 3). The only exception is amphorae, which were predominantly imported, although only 2006 entries are recorded as amphorae (pithoi and storage jars were locally produced and included in the much higher counts for coarse wares), which is not surprising for an inland settlement such as Jerash. The typological variation of local ceramics was also very limited: each functional category was represented by a single or a few types (Möller 2017).

Possible chronological changes in this trend can be observed. Figures 4 and 5 reveal that the absolute numbers of ceramics that could be dated through stratified ${ }^{14} \mathrm{C}$-dated organic material, or associated ceramics, glass and coins, vary strongly per period, yet all reveal the same pattern of a tiny fraction of imports in all periods. The largest proportions of imports (4.35\%) are for the Early Islamic period evidenced through 1022 ceramic finds from ${ }^{14} \mathrm{C}$-dated contexts, whereas for all other periods, the proportions are typically much lower than $1 \%$.

\section{Ceramic Data Patterns in the Wider Region}

This data pattern from Jerash might be comparable to that of Gadara, Scythopolis, Pella, Philippopolis, Canatha and Abila: similar-sized or smaller cities fairly close by, which are equally far removed from the main coastal ports. Do sites in the region show the same limited presence of imports and regional products, or is the ceramic data pattern in Jerash exceptional?

Our recent literature review (Bes et al., 2020) focused on the Roman- to Umayyadperiod ceramic profiles of Damascus, Philippopolis, Canatha, Bostra, Capitolias, Gadara, Abila, Hippos, Tiberias, Scythopolis, Pella, Philadelphia, Neapolis, Samaria, Dora and Caesarea Maritima. It revealed that the archaeological processing and limited publication of ceramic finds regarding most of these sites put a strong limit on our

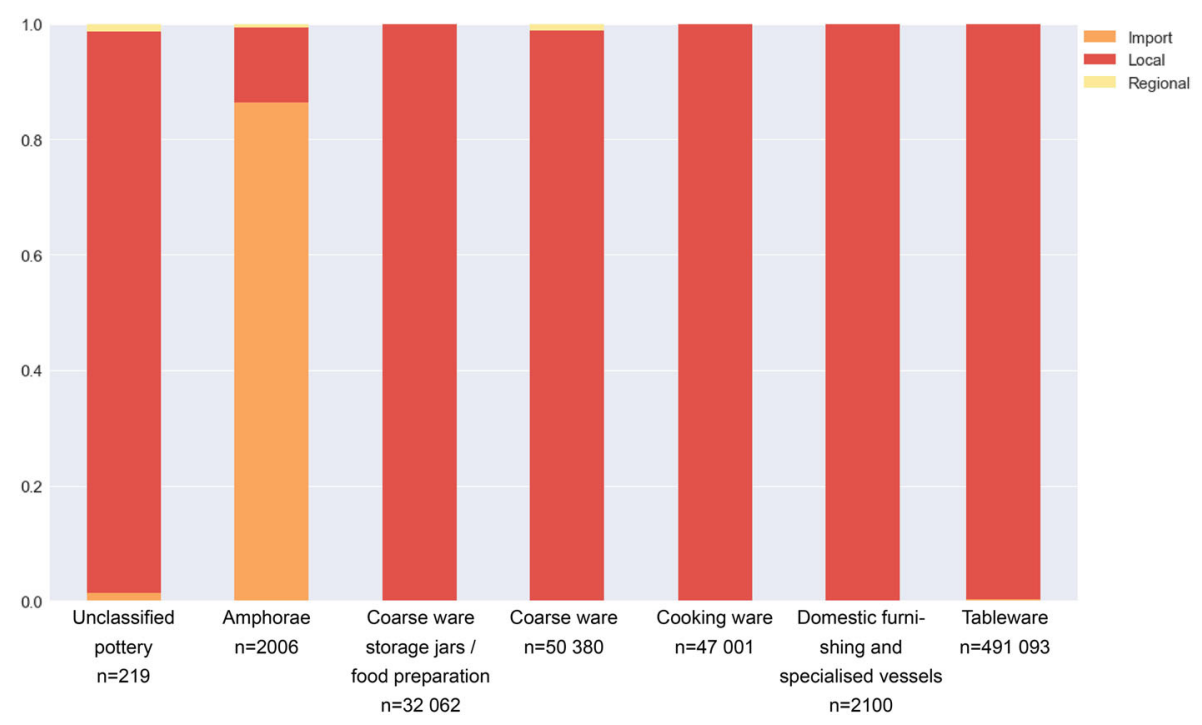

Fig. 3 The proportion of local, regional and imported pottery grouped by functional categories 

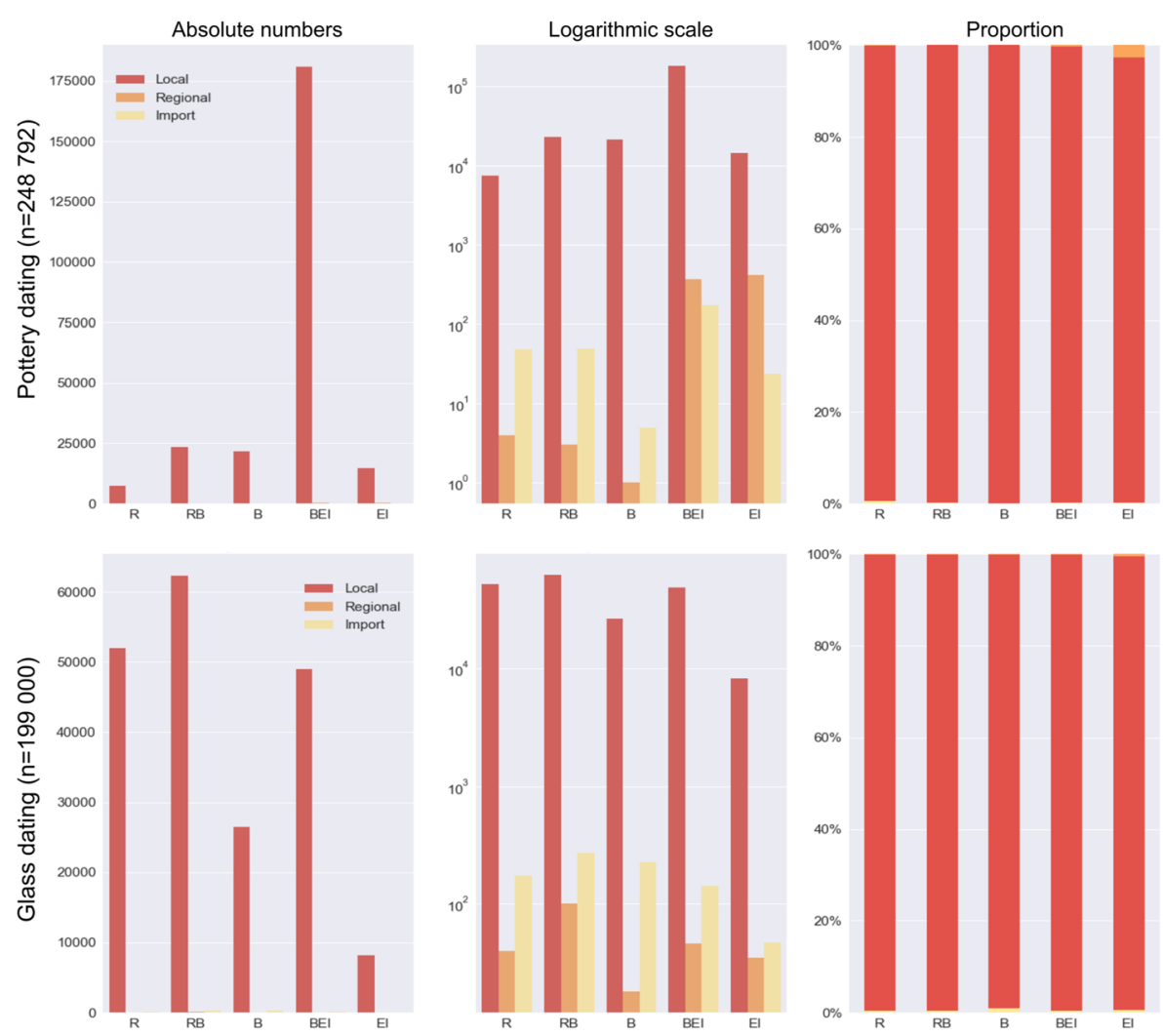

Fig. 4 Change through time of counts of ceramics from contexts dated through pottery (top) and glass (bottom). Here and in Fig. 5, the left column shows absolute numbers, the middle column shows absolute numbers with a logarithmic $y$-axis to display differences in the tiny amounts of imported and regional ceramics and the right column shows the relative proportions; period abbreviations: Roman (R), Roman and Byzantine (RB), Byzantine (B), Byzantine and Early Islamic (BEI) and Early Islamic (EI)

ability to answer this question (Fig. 6; summaries per site included in Online Resource 2). However, the literature review allows us to make three general observations. First, most and possibly all sites were involved in some level of pottery manufacture of one or more functional categories within their urban areas or their vicinity. Second, these ceramic products catered for a considerable if not generally a predominant share of the inhabitants' ceramic requirements. Third, long-distance imported pottery is relatively more common and more varied at coastal compared to inland sites, where we hypothesise (based on our literature review) it is negligible in terms of quantity and variety of wares and/or types.

It is unlikely that other sites allow for a reliable formal comparison with the patterns observed for the evidence stemming from the Jerash Northwest Quarter (but see Rasson-Seigne and Seigne 2020a; Rasson-Seigne and Seigne 2020b; Uscatescu 2020). Exhaustive quantification of excavated ceramics is rare in eastern Mediterranean Classical Archaeology. If any full quantification takes place, it tends to focus on imported ceramics used as indicators of inter-regional interactions and whose wellstudied typologies are crucial for dating of excavated contexts (Bes et al., 2020; see 

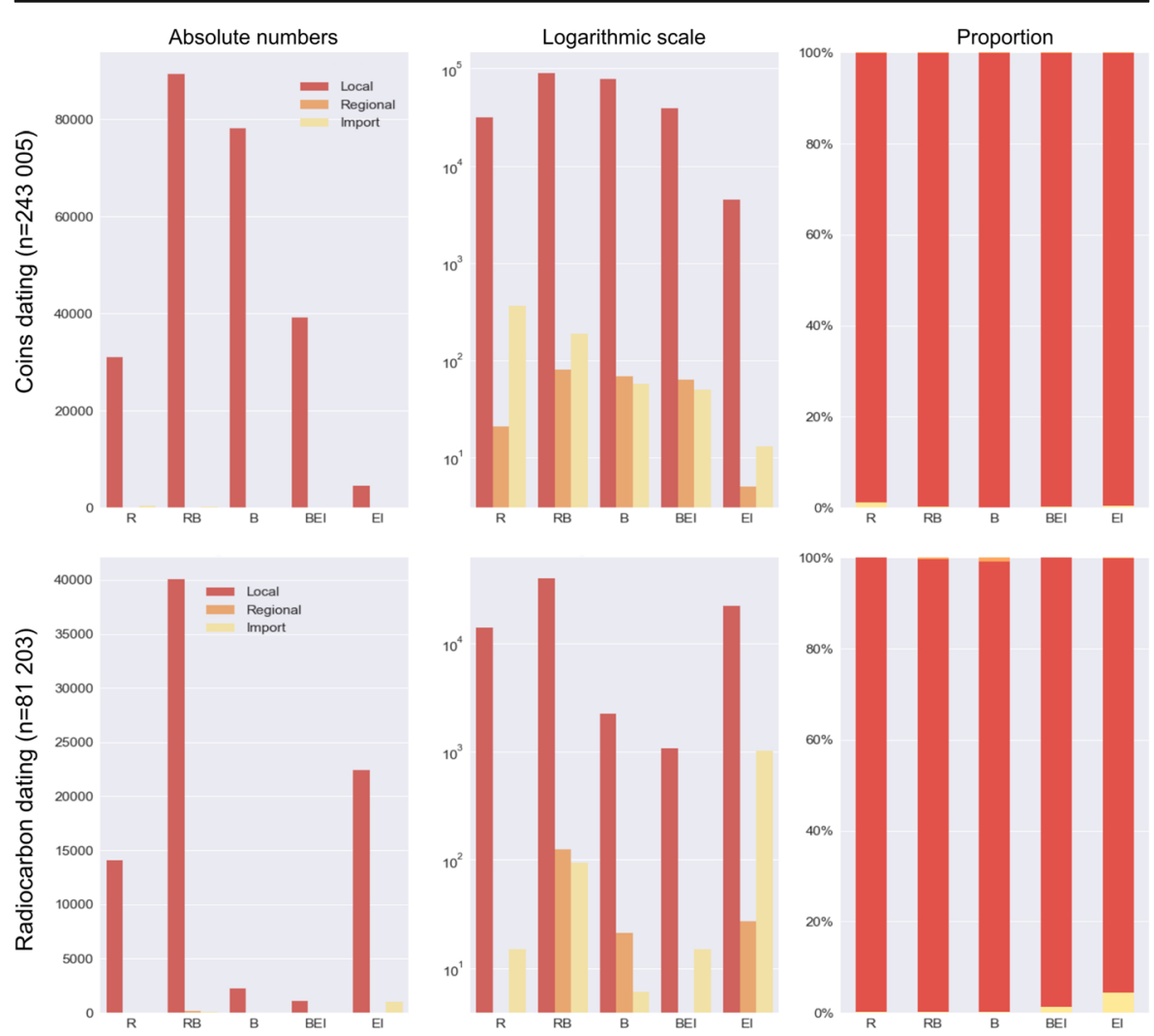

Fig. 5 Change through time of counts of ceramics from contexts dated through coins (top) and ${ }^{14} \mathrm{C}$ (bottom)

Reynolds 2010, for a counter example). However, this practice has led to a poor knowledge of local ceramic production (e.g. archaeometrical characterisation, typology, chronology) and intra-regional distribution. Given that locally and intra-regionally distributed ceramics almost certainly make up the bulk of all ceramic assemblages (Bes et al., 2020), this situation puts a constraint on our ability to understand local production and regional economies for much of the ancient eastern Mediterranean.

We believe that once fully quantified data collection and analysis becomes more common, computational simulation will prove invaluable in our explanatory efforts. We will therefore turn our attention again to Jerash as an example to illustrate the potential of this approach.

\section{Explaining Local Craft Production in Gerasa}

What could explain the centuries-long reliance on the local pottery and the limited morphological diversity? Here, we consider a range of factors that could plausibly be postulated (see also Romanowska et al., 2018).

Geographical Location and Integration in Ancient Transport Systems Unlike some other mid-sized cities in the area, Gerasa was not located along the main roads of the 


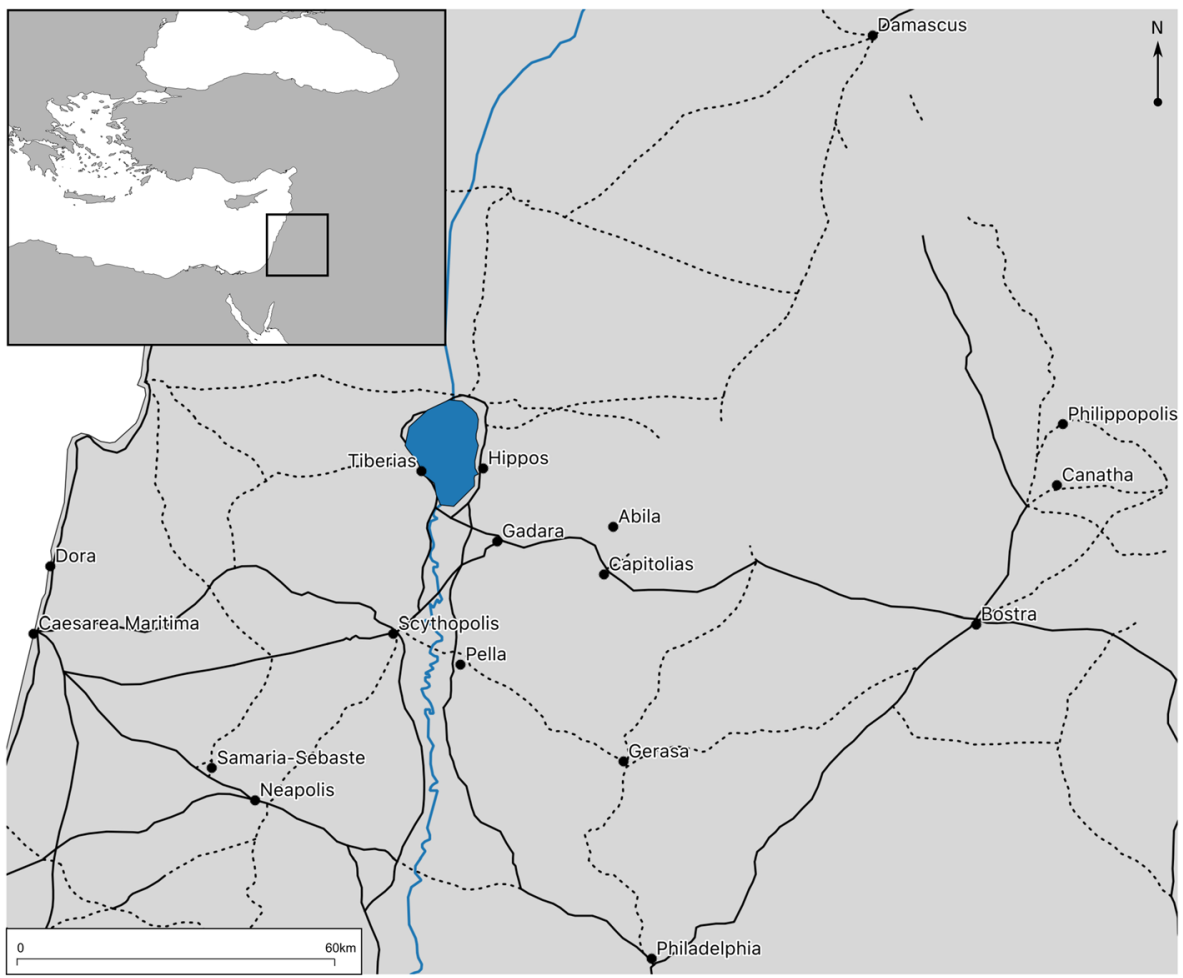

Fig. 6 Sites in the wider area included in our overview of published ceramics (Bes et al., 2020). Major Roman Imperial era roads marked as solid black lines and minor roads as dotted lines (source roads: Talbert 2000; Ancient World Mapping Centre 2012)

periods under discussion (Fig. 6). It was removed from coastal ports, which would have negatively affected the diversity of available imported and regional goods. However, it was well integrated into the ancient overland transport system through secondary roads.

Population Size Gerasa was a mid-sized urban settlement like many other comparable settlements in the region, with a population of some 10,000-50,000 people (recently estimated at 15,500 by Hanson and Ortman 2017). It cannot be compared with eastern metropolis like Antioch or Alexandria, which we can assume would have exercised a gravitational pull on craft products offered by traders competing for a slice of the considerable demand of the region. We can expect a more limited attraction of Jerash than that exerted by larger cities closer by such as Damascus and Jerusalem.

Both of these scenarios may account for a certain level of dominance of one type of ceramics over another, but their explanatory power behind the observed disproportion seems limited.

Good Conditions for Large-Scale Ceramic Production The city's natural setting offered plentiful availability of wood and olive pits for fuel, water and, in particular, highquality clay. Analyses of ceramic thin sections revealed that no temper was used and no levigation was necessary (Möller 2017). These conditions fostered specialised and efficient local craft production, allowing this settlement to host workshops that could 
supply for all of its local demand and a little more, which was distributed in the area (Uscatescu 2019). There might therefore not have been a need for imported ceramics like tablewares, and likely, the local product could outcompete imports in terms of price and immediate availability, thanks to its efficient and cheap production process focused on providing a full set of the pottery forms and types to satisfy all local functional needs.

Self-sufficiency in Agricultural Products The wider territory of Jerash includes good water sources and fertile areas suitable for the production of olive oil, wine, flax and other staple goods (Stott et al., 2018; Lichtenberger and Raja (forthcoming)). Oil production, in particular, is evidenced through finds of oil presses and the use of olive pits as fuel (Kalaitzoglou et al., 2013). It is assumed that the community of Jerash was largely self-sufficient concerning oil and the same could possibly be said for flax and wine, suggesting we would not expect to find large numbers of amphorae from overseas or an abundance of tableware, cooking wares and coarse wares produced in overseas areas and transported along with staple goods (e.g. African red slip ware) (for amphorae cf. Duplessis et al., 2020; Uscatescu 1996, 172-179; Uscatescu 2020). Again, whether this alone (or even in combination with the above factors) could explain the almost complete lack of non-local ceramics is uncertain.

\section{Simulating Product Preference}

The above factors are relevant potential mechanisms impacting pottery distribution, and we consider them plausible to potentially explain at least part of the data pattern. But their ability to explain the extreme dominance of local ceramics in Jerash is far less certain and requires formal testing. Would any one of these factors or a combination of them lead to such an extreme dominance of local ceramics for over six centuries?

In this paper, we wish to focus on a fifth explanatory factor that has received far less attention: the social processes behind ceramic consumption guided by heterogeneous preferences for goods.

We argue preference is a relevant theory since the six centuries' long dominance of local ceramics reveals a degree of conservatism and self-sufficiency that could be actively enforced through individual and collective attitudes. Preference for different craft products in this ancient Mediterranean context could be theorised in a diversity of ways (e.g. Ray 2009; Van Oyen 2016; Beck 2020). Not only the more limited supply and possibly higher price of imported goods could have influenced people's decision to use a local pot over a non-local one. Individuals' preferences for the perceived intrinsic values of local VS imported goods could have equally left traces in the archaeological record. The changing of individuals' preferences based on the goods preferred by the majority or minority of the community could also have resulted in material traces. Was the local Jerash product consciously preferred to support the local craft economy, or because the local product was perceived as being of higher quality? Or was the tendency to buy items that were more popular on the market, or less so, an important factor? A diversity of hypotheses of product preference can be formulated, and they bring an individual-based local perspective to discussions of ceramic distributions, 
rather than deterministically considering them the result of Jerash's location, ecological setting and size.

Studies of such theories of product preference are common in economics (Gintis 2009), where they have been shown to reveal unexpected and counterintuitive results: both preference-biased and unbiased scenarios can lead to an inferior product (price- or perception-wise) becoming the most successful product on a market (Arthur 1989). Moreover, straightforward intuition-based conclusions should be avoided when formulating theories about individual decision-making, since individuals' actions can affect each other in unpredictable ways, and they are most appropriately studied with formal modelling methods like agent-based simulation (Brughmans et al., 2019; Arthur 2006; Romanowska et al., 2019).

Here, we aim to evaluate plausible processes of individuals' product preference that can give rise to the extreme dominance of local ceramics. This allows us to better place individuals' buying behaviours and decision-making into our theories as explanatory factors for Jerash's ceramic data and to reveal the potential of the simulation approach for other explanatory factors and archaeological data patterns.

\section{Method}

An agent-based model was created to represent diverse processes of preference formation and their impacts on ceramics proportions (Romanowska and Carrignon 2021). The model consists of 100 individual agents characterised by a vector of boolean preferences for three goods representing local, regional and imported ceramics (where 1 is preference for a good and 0 non-preference). The number of different goods an agent can have a preference for is limited, and once this limit is reached, one preferred good will be randomly removed from the list. At each simulation time step, agents will copy others' preferences with a probability determined by one of six hypothesised behavioural scenarios:

1. Neutral (Fig. 7a): individuals copy each other randomly, and each product has equal probability of being selected.

2. Intrinsic value (Fig. 7b): individuals are given a predefined preference distribution representing our theory of how strong the preference for one product over others is. These can be interpreted as an inherent value of one product over another coupled with a fully rational choice reflecting economic utility such as quality, price or value for money ('I want this good because it is better quality/cheaper/bigger') or as a personal preference for one product over another ('I want this good because I like it'). This obviously aggregates very different explanations, but disentangling these causal mechanisms would require data much richer than that available. Whether Jerash's inhabitants bought local pottery because it was cheaper, sturdier or just because they liked it more would all produce the same pottery frequency pattern. Thus, at this point, we are unable to differentiate between these explanatory factors, and until more and different types of data become available, we have to group them under one scenario.

3. Frequency conformist (Fig. 7c): individuals are more likely to copy popular local products ('I want what my peers prefer'). 
4. Frequency anticonformist (Fig. 7d): individuals are more likely to copy unpopular products ('I want the exotic good that few prefer').

5. Intrinsic value + frequency conformist (Fig. 7e): the individual's personal preference and the popularity of products in the local population are combined ('I want it because I like it and many others do too').

6. Intrinsic value + frequency anticonformist (Fig. 7f): the individual's personal preference and the most popular product in the population are combined ('I want it because I like it and few prefer it').

(a) Neutral

Probability:

\begin{tabular}{|l|l|l|}
\hline A & B & C \\
1 & 1 & 1 \\
\hline
\end{tabular}

(b) Intrinsic value

\begin{tabular}{l|c|c|c|}
$\begin{array}{l}\text { Individual } \\
\text { preference: }\end{array}$ & $\mathbf{A}$ & $\mathbf{B}$ & $\mathbf{C}$ \\
Probability: & 0.6 & 0.2 & 0.2 \\
& 0.6 & 0.2 & 0.2 \\
\hline
\end{tabular}

(d) Frequency anticonformist

\begin{tabular}{l|c|c|c|}
\hline $\begin{array}{l}\text { Population } \\
\text { preference: }\end{array}$ & $\begin{array}{c}\text { A } \\
0.5\end{array}$ & $\mathbf{B}$ & $\mathbf{C}$ \\
\hline Probability: & 0.5 & 0.2 \\
\hline & 0.5 & 0.3 & 0.2 \\
\hline
\end{tabular}

(e) Intrinsic value + frequency conformist

\begin{tabular}{l|c|c|c|}
$\begin{array}{l}\text { Individual } \\
\text { preference: }\end{array}$ & $\mathbf{A}$ & $\mathbf{B}$ & $\mathbf{C}$ \\
$\begin{array}{l}\text { Population } \\
\text { preference: }\end{array}$ & 0.6 & 0.2 & 0.2 \\
\hline Probability: & $1.1 / 2$ & $0.5 / 2$ & $0.4 / 2$ \\
\hline
\end{tabular}

\begin{tabular}{l|c|c|c|} 
Population & A & B & C \\
preference: & 0.5 & 0.3 & 0.2 \\
Probability: & 0.5 & 0.7 & 0.8 \\
\hline
\end{tabular}

(f) Intrinsic value + frequency anticonformist

\begin{tabular}{|c|c|c|c|}
\hline $\begin{array}{l}\text { Individual } \\
\text { preference: }\end{array}$ & $\begin{array}{c}\mathbf{A} \\
0.6\end{array}$ & $\begin{array}{c}\text { B } \\
0.2\end{array}$ & $\begin{array}{c}\mathbf{C} \\
0.2\end{array}$ \\
\hline $\begin{array}{l}\text { Population } \\
\text { preference: }\end{array}$ & 0.5 & 0.3 & 0.2 \\
\hline obability: & $1.1 / 3$ & $0.9 / 3$ & $1.0 / 3$ \\
\hline
\end{tabular}

\section{(g) Example output}

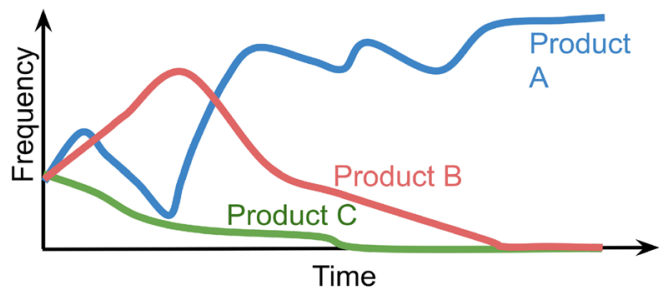

Fig. 7 Example probability matrices for the six hypotheses explored with our model 
These scenarios produce diverse matrices of probabilities of all the products, which are used to determine what preference for a product each agent copies at each time step. Copying follows a probabilistic mechanism known as a roulette wheel or fitness proportional selection (Online resource 3; Romanowska and Carrignon 2021). In simple terms, in the roulette wheel algorithm, the probability of choosing any one of the options is proportional to the intrinsic value of the option to be chosen. For example, product A may have a fitness of $50 \%$, while product $\mathrm{B}$, a fitness of $25 \%$, in which case product A will be chosen on average twice as often as product B. Over time, this leads to changes in the frequency of goods in the simulation, since some products have a higher chance of being copied than others, while all of them have the same probability of being removed: some come to dominate the market while others disappear. We record and compare the total amount of each product over the full duration of the simulation (500 time steps); i.e. we do not merely count the dominant product at the end of a simulation experiment, but rather assume each time step is a deposition action, and we look at products' proportions for the accumulated depositions (Fig. 7g). Under which hypothesised behavioural scenarios of individual product preference do we get proportions of goods that are similar to the ceramic record of Jerash?

\section{Results}

The simulation results are presented in Fig. 8, where each boxplot represents how often one product was selected (used here as a reflection of deposition) by 100 agents over 500 simulation time steps in 100 repetitions of the experiment: i.e. they represent the cumulative deposition of ceramics over time simulated 100 times. We repeat each experimental setup 100 times due to the probabilistic elements in our model, to better understand the distribution of possible simulation outcomes. Additional experiments reported in Online Resource 3 confirm these results are not sensitive to changing the number of repetitions per experiment, the number of agents, the number of simulation time steps and the random mutation probability. We can now compare these simulated ceramic patterns with the overall archaeologically observed ceramic data pattern presented above, 99\% local ceramics and 1\% other ceramics. Figure 8 shows the distance of simulation results to the data, calculated as the sum of the absolute value of the difference between the logarithm of the observed frequencies and the simulated frequencies (formal definition in Online Resource 3).

These results show that some theories of local product preference are less plausible. Individuals in Jerash clearly did not select products at random independent of what was happening on the local market (i.e. neutral model, Fig. 8a). Although we did not consider this a plausible theory, it is crucial to verify it formally. Had such a random copying process shown a good fit with the archaeological record (meaning the actual complex social processes cannot be distinguished from random processes), then our ability to identify plausible product preference theories would have been very limited. Neither did consumers have a strong tendency to buy a product, which was preferred by the least number of other consumers (anticonformist frequency bias, Fig. 8c, g, h): i.e. assuming the local ceramics were preferred less than others because; for example, most consumers preferred imports; then, even a tendency towards buying that local product would not lead to it being consumed vastly more than other products. Crucially, if the 


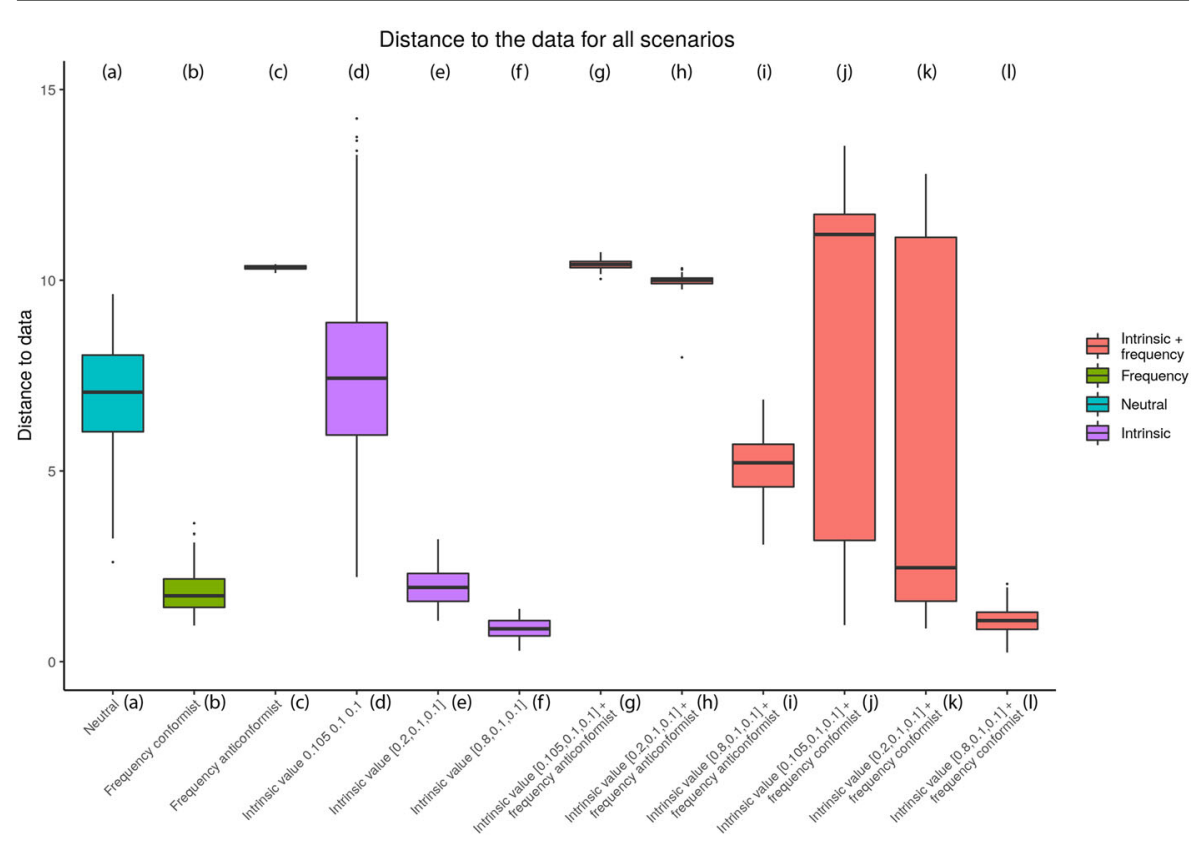

Fig. 8 Results of different simulation experimental setups. Each boxplot represents how close the simulated proportions of local, regional and imported ceramics are to the archaeologically observed ceramics (100 repetitions; 500 time steps; 100 agents)

local product was only considered to have a slightly higher intrinsic value, then it would not have dominated (i.e. low intrinsic value bias; Fig. 8d, j). This last result highlights our need to be specific when formulating explanatory theories and that different theories of product preference can give rise to different and sometimes counterintuitive results.

However, the simulation results also revealed three more plausible theories of local product preference. First, if the majority of the population preferred the local product at some point, then a tendency towards buying this product would always result in it being vastly more represented in the archaeological record (i.e. conformist frequency bias; Fig. 8b). Second, the local product can dominate if its intrinsic value was considered at least double as much as that of others (i.e. high intrinsic value; Fig. 8e, f). This implies that a small difference in the intrinsic value assessment of the local product alone can explain it being the majority but does not explain the extreme proportions seen for Jerash (e.g. Fig. 8d): local buyers would need to have preferred it much more than imported or regional ceramics. We would equally expect to see a much higher representation of imported or regional wares in the archaeological record if their intrinsic value was considered higher than the local product (if availability allowed for this). Third, the local product could equally have dominated, if its intrinsic value was vastly higher than that of imported or regional products (e.g. eight times higher) combined with a tendency for buying the product preferred by most (i.e. conformist frequency bias + intrinsic value bias $>0.8$; Fig. 81). The same applies if the inherent value is only twice the alternative, although there is a much higher variance in the results in that scenario (i.e. conformist frequency bias + intrinsic value bias $>0.2$; Fig. 
$8 \mathrm{k})$. This third result reveals that a combination of preference processes could have been part of causing the dominance of local ceramics.

\section{Discussion and Conclusions}

\section{Full Quantification and Eastern Mediterranean Classical Archaeology}

The theories we tested through simulation were inspired by the extreme nature of the ceramic data pattern identified through the full quantification recording strategy employed at Jerash. A majority of locally produced ceramics can certainly be expected for a middle-sized inland ceramic production centre such as Gerasa. But the proportions identified were surprising, because ceramics have never before been fully quantified at the site and because recovery biases in eastern Mediterranean Classical Archaeology tend to lead to the overrepresentation of imported ceramics. Our regional literature review (Bes et al., 2020) suggests that the same is true for almost all sites in the region. This means we simply cannot evaluate to what extent the ceramic data pattern identified for Jerash is exceptional within the wider region, because we do not have any reliable and accessible quantitative evidence to evaluate what is meant by an expected majority of locally produced ceramics (or regional ceramics for nonproduction centres), $75 \%$ or $99 \%$ of all ceramics? We are currently equally unable to evaluate the extent to which Gerasa was a (major) supplier of ceramics for the region as a whole: were Gerasa-made ceramics equally dominant at other sites in the region or are these markets dominated by their local products?

These insights reveal a need for more rigorous recording and full quantification of ceramics in eastern Mediterranean Classical Archaeology. Through the example of a particularly robust ceramic data pattern at Jerash, we have illustrated some of the advantages of a fully quantified recording and publishing strategy: (1) archaeological data patterns can be identified that can confirm or modify the intuitive expectations of material specialists; (2) the robustness or diversity of archaeological data patterns can be explored with reference to their representation in different types of contexts (Fig. 2) or using diverse dating techniques (Figs. 4 and 5); e.g. focusing quantitative data collection on selected contexts only (like trench $\mathrm{V}$ in the Northwest Quarter with a higher proportion of imports) might not reveal the ceramic data pattern of the site or diversity of its ceramic profile through time, whereas full quantification offers the flexibility to identify this diversity through later quantitative data analysis; (3) formal comparisons with other sites quantified ceramic assemblages are possible, as are formal assessments of the plausibility of explanatory hypotheses.

Finally, we emphasise the need for more petrographic and chemical studies of pottery not destined for inter-regional distribution. This is necessary future work in light of this pottery presumably forming the majority of excavated material, including categories that might well have played a role of some significance in regional distribution patterns. We can assume that most, if not all, of the cities studied in the literature review (Bes et al., 2020) were involved 
in local and/or close-regional pottery manufacture for one or more parts of the Roman, Byzantine and Umayyad periods. More integrated research programs are required that document and analyse these local ceramic products, their production contexts and distributions (such as Bar-Nathan and Atrash 2011; Levantine Ceramics Project, 2012-2020). If we wish to get a more thorough grasp of ceramic craft production and distribution in the eastern Mediterranean, we will need to increase and diversify our efforts at understanding local and regional ceramic products. These datasets will then become the cornerstone of modelling studies which can help us unravel complex interactions between actors and processes that drove craft production, exchange and discard.

\section{Simulation Results and Open Science}

Our simulation results reveal that preference for locally produced ceramics at Jerash might be a plausible theory, but only if its intrinsic value was considered rather high in comparison to other goods, or if it was preferred by a majority of the population, and there was a tendency to follow this majority preference (or a combination of these factors). However, it is crucial to emphasise that with these experiments, we did not aim to reveal processes completely explaining the dominance of local ceramics in Jerash, because they only concern product preference. Moreover, they also represent ceramics in a very specific way: the model assumes local, regional and imported ceramics are commodities that were perceived as different products by the ancient inhabitants of Gerasa. We consider this an appropriate and necessary assumption for testing our theories about preference for the local product, because the assumption lies at the core of the data pattern we aim to understand, but it is by no means an unproblematic assumption (Ray 2009; Van Oyen 2017). Rather, the relevance of our simulation approach lies in the ability to add specific mechanisms of product preference to our future explanatory efforts. This method has identified that specific processes of product preference should be considered plausible factors alongside the economic (limited supply of imported ceramics and high availability of local ceramics), locational and environmental factors discussed above.

The alternative locational and economic factors are more commonly theorised and studied in their abstract form in Classical Archaeology, and they should equally be formally explored, and simulation approaches might well prove useful for this purpose. However, we believe complex social processes like product preference are underrepresented in theoretical debates in Classical Archaeology, they are insufficiently specified, and their effects are rarely problematised (Carrignon et al., 2015; Coto-Sarmiento et al., 2018). It is a commonly raised concern in archaeology that computational models operate on strictly rational, economic and deterministic frameworks not compatible with our understanding of individuals as often driven by suboptimal solutions, personal preferences and potentially not rational decisions (Van Oyen 2017). Here, our aim was to demonstrate that this association between rational/ mechanistic and formal/computational is an artificial one. To this end, we have introduced a model that incorporates personal, and not necessarily rational, choices. 
Our simulation results revealed the need for and the possibility of hypothesising how some products might have been preferred over others and how some such processes simply do not lead to intuitive results (e.g. a very low difference in intrinsic value assessment is insufficient). This is particularly true for a number of sites in the region for which several different types of data are available. These datasets could be easily leveraged to unravel the complex interactions between different factors (price, availability, quality, etc.) which shaped consumer choices. The simulation approach applied here has great potential for Classical Archaeology and should be more commonly applied for evaluating the plausibility of different explanatory hypotheses (Brughmans et al., 2019). We equally want to highlight the potential of the overall open quantitative methodological pipeline we have applied for this study: our approach is openly documented from data analysis scripts to simulation code (Romanowska 2020; Romanowska and Carrignon 2021), allowing the results to be reproduced and the methods to be reused.

In sum, we highlight the need for open, transparent and robust methods to be used throughout the life of an archaeological fieldwork research project. This applies not only to data collection and management but also to analysis and interpretation through the means of simulation or other formal modelling methods.

Funding This work was supported by the Carlsberg Foundation, the Danish National Research Foundation under the grant DNRF119-Centre of Excellence for Urban Network Evolutions (UrbNet), Deutsche Forschungsgemeinschaft (LI 978/4), Deutscher Palästina-Verein, the EliteForsk initiative of the Danish Ministry of Higher Education and Science, H. P. Hjerl Hansens Mindefondet for Dansk Palæstinaforskning, the Leverhulme Trust funded MERCURY project (ECF-2016-197), the European Union's Horizon 2020 Research and Innovation Programme under the Marie Skłodowska-Curie grant agreement no 754513 and the Aarhus University Research Foundation. Open access fees by the DNRF119 grant directed by Rubina Raja.

Data Availability All data used in this paper is available open access in Lichtenberger and Raja (2020c).

Code Availability The agent-based model code is available open access in Romanowska and Carrignon (2021).

The data analysis script is available open access in Romanowska (2020).

\section{Declarations}

Conflict of Interest The authors declare no conflicts of interest.

Open Access This article is licensed under a Creative Commons Attribution 4.0 International License, which permits use, sharing, adaptation, distribution and reproduction in any medium or format, as long as you give appropriate credit to the original author(s) and the source, provide a link to the Creative Commons licence, and indicate if changes were made. The images or other third party material in this article are included in the article's Creative Commons licence, unless indicated otherwise in a credit line to the material. If material is not included in the article's Creative Commons licence and your intended use is not permitted by statutory regulation or exceeds the permitted use, you will need to obtain permission directly from the copyright holder. To view a copy of this licence, visit http://creativecommons.org/licenses/by/4.0/. 


\section{References}

Ancient World Mapping Center. (2012). Road information derived from Talbert. In J. A. Richard \& R. S. Bagnall (Eds.), 2000. Barrington atlas of the Greek and Roman world. Princeton, N.J.: Princeton University Press http://awmc.unc.edu/awmc/map_data/shapefiles/ba_roads/ (accessed 16/07/2020).

Arthur, W. B. (1989). Competing technologies, increasing returns, and lock-in by historical events. The economic journal, 99(394), 116-131.

Arthur, W. B. (2006). Out-of-equilibrium economics and agent-based modeling. In L. Tesfatsion \& K. L. Judd (Eds.), Handbook of computational economics volume 2 (pp. 1552-1564). Elsevier.

Barfod, G. H., Freestone, I. C., Lichtenberger, A., Raja, R., \& Schwarzer, H. (2018). Geochemistry of Byzantine and Early Islamic glass from Jerash, Jordan: typology, recycling, and provenance. Geoarchaeology, 33(6), 623-640. https://doi.org/10.1002/gea.21684.

Bar-Nathan, R., \& Atrash, W. (2011). Baysān. The theater pottery workshop (Israel Antiquities Authority Reports 48) (Bet She'an II). Jerusalem: Israel Antiquities Authority.

Beck, H. (2020). Localism and the ancient Greek city-state. Chicago: University of Chicago Press.

Bes, P., Brughmans, T., Lichtenberger, A., Raja, R., \& Romanowska, I. (2020). Ceramics in cities in context. An overview of published Roman Imperial to Umayyad pottery in the Southern Levant. In A. Lichtenberger \& R. Raja (Eds.), Hellenistic and Roman Gerasa. The archaeology and history of a Decapolis city (Jerash papers vol. 5) (pp. 55-118). Turnhout: Brepols publishers.

Brughmans, T., Hanson, J. W., Mandich, M. J., Romanowska, I., Rubio-Campillo, X., Carrignon, S., CollinsElliott, S., Crawford, K., Daems, D., Fulminante, F., de Haas, T., Kelly, P., del Carmen Moreno Escobar, M., Paliou, E., Prignano, L., \& Ritondale, M. (2019). Formal modelling approaches to complexity science in Roman studies: a manifesto. Theoretical Roman Archaeology Journal, 2(1), 1-19. https://doi.org/10. 16995/traj.367.

Carrignon, S., Montanier, J.-M., \& Rubio-campillo, X. (2015). Modelling the co-evolution of trade and culture in past societies. In M. D. R. L. Yilmaz, W. K. V. Chan, I. Moon, T. M. K. Roeder, \& C. Macal (Eds.), Proceedings of the 2015 Winter Simulation Conference (pp. 3949-3960).

Coto-Sarmiento, M., Rubio-campillo, X., \& Remesal, J. (2018). Identifying social learning between Roman amphorae workshops through morphometric similarity. Journal of Archaeological Science, 96(April), 117-123. https://doi.org/10.1016/j.jas.2018.06.002.

Duplessis, S., di Napoli, F., \& Seigne, J. (2020). Les timbres amphoriques trouvés à Jerash. In A. Lichtenberger \& R. Raja (Eds.), Hellenistic and Roman Gerasa: the archaeology and history of a Decapolis city (Vol. 5, pp. 145-172). Turnhout: Brepols Publishers.

Gintis, H. (2009). Game theory evolving: A problem-centered introduction to modeling strategic behavior (2ed.). Princeton: Princeton University Press.

Hanson, J. W., \& Ortman, S. G. (2017). A systematic method for estimating the populations of Greek and Roman settlements. Journal of Roman Archaeology, 30, 301-324.

Kalaitzoglou, G., Lichtenberger, A., \& Raja, R. (2013). Preliminary report of the second season of the DanishGerman Jarash Northwest Quarter Project 2012. In Annual of the Department of Antiquities of Jordan 57 (pp. 57-79). Amman: Department of Antiquities.

Kalaitzoglou, G., Lichtenberger, A., Möller, H., \& Raja, R. (forthcoming). Preliminary report of the sixth season of the Danish-German Jerash Northwest Quarter Project 2016. In Annual of the Department of Antiquities of Jordan 61. Amman: Department of Antiquities.

Levantine Ceramics Project (2012-2020). Available at: http://www.levantineceramics.org (accessed 16/07/ 2020).

Lichtenberger, A. (2003). Kulte und Kultur der Dekapolis: Untersuchungen zu numismatischen, archäologischen und epigraphischen Zeugnissen. Wiesbaden: Harrassowitz.

Lichtenberger, A., \& Raja, R. (2016). A newly excavated private house in Jerash: reconsidering aspects of continuity and change in material culture from Late Antiquity to the Early Islamic period. Antiquité Tardive, 24, 317-359.

Lichtenberger, A., \& Raja, R. (2017). Mosaicists at work: the organisation of mosaic production in Early Islamic Jerash. In Antiquity, 91(358), 998-1010. https://doi.org/10.15184/aqy.2017.66.

Lichtenberger, A., \& Raja, R. (2019). Introduction: the conundrum of chronologies of the Byzantine and Umayyad periods in Jerash. In A. Lichtenberger \& R. Raja (Eds.), Byzantine and Umayyad Jerash reconsidered. Transitions, transformations, continuities. Jerash Papers 4 (pp. 1-6). Turnhout: Brepols Publishers.

Lichtenberger, A., \& Raja, R. (2020a). Hellenistic and Roman Gerasa: the archaeology and history of a Decapolis city (Jerash Papers Vol. 5). Turnhout: Brepols Publishers. 
Lichtenberger, A., \& Raja, R. (2020b). Late Hellenistic and Roman Antioch on the Chrysorhoas, also called Gerasa. A reappreciation of the evidence in the light of the findings of the Danish-German Jerash Northwest Quarter Project (2011-2017). In A. Lichtenberger \& R. Raja (Eds.), Hellenistic and Roman Gerasa: the archaeology and history of a Decapolis city (Vol. 5, pp. 7-54). Turnhout: Brepols Publishers.

Lichtenberger, A., \& Raja, R. (2020c). Pottery from the Northwest Quarter, Jerash, Jordan excavated by the Danish-German Jerash Northwest Quarter Project. Zenodo. https://doi.org/10.5281/ZENODO.4337026

Lichtenberger, A., \& Raja, R. (forthcoming). Seasonality and urban economy: the case of Gerasa in the Decapolis. In A. Lichtenberger \& R. Raja (Eds.), The archaeology of seasonality. Turnhout: Brepols Publishers.

Möller, H. (2017). Ceramics in context: interpreting life through pottery. In A. Lichtenberger \& R. Raja (Eds.), Gerasa/Jerash: from the urban periphery (pp. 59-65). Aarhus: Fællestrykkeriet AUTRYK.

Orfanou, V., Birch, T., Lichtenberger, A., Raja, R., Barfod, G. H., Lesher, C. E., \& Eger, C. (2020). Copperbased metalwork in Roman to early Islamic Jerash (Jordan): insights into production and recycling through alloy compositions and lead isotopes. Journal of Archaeological Science: Reports, 33, 102519. https://doi.org/10.1016/j.jasrep.2020.102519.

Raja, R. (2012). Urban development and regional identity in the eastern Roman provinces, 50 BC-AD 250: Aphrodisias, Ephesos, Athens, Gerasa. Copenhagen: Museum Tusculanum Press.

Rasson-Seigne, A.-M., \& Seigne, J. (2020a). Les productions de céramiques locales de Jerash au début de la période romaine (1er siècle avant J.-C. - IIe siècle après J.-C.): influences et diffusion. In A. Lichtenberger \& R. Raja (Eds.), Hellenistic and Roman Gerasa: the archaeology and history of a Decapolis city (Vol. 5, pp. 119-128). Turnhout: Brepols Publishers.

Rasson-Seigne, A.-M., \& Seigne, J. (2020b). La céramique importée à Jerash pendant l'èpoque romaine (fin Ier siècle avant J.-C. - fin IIIe siècle après J.-C.): l'apport des fouilles du sanctuaire de Zeus. In A. Lichtenberger \& R. Raja (Eds.), Hellenistic and Roman Gerasa: the archaeology and history of a Decapolis city (Vol. 5, pp. 129-144). Turnhout: Brepols Publishers.

Ray, N. M. (2009). Household consumption in ancient economies: Pompeii and the wider Roman world. PhD thesis. University of Leicester.

Reynolds, P. (2010). Trade networks of the east, 3rd to 7th centuries: the view from Beirut (Lebanon) and Butrint (Albania) (fine wares, amphorae and kitchen wares). In S. Menchelli, S. Santoro, M. Pasquinucci, \& G. Guiducci (Eds.), Late Roman coarse wares, cooking wares and amphorae in the Mediterranean, archaeology and archaeometry, comparison between western and eastern Mediterranean, BAR International Series 2185 (Vol. I, pp. 89-114). Oxford: Archaeopress.

Romanowska, I. (2020). izaromanowska/Pottery Jerash DA: Pottery Jerash DA. Zenodo. https://doi.org/ 10.5281/ZENODO.4337582.

Romanowska, I., \& Carrignon, S. (2021). Agent-based modelling simulation of consumer preferences in ancient Jerash. Zenodo. https://doi.org/10.5281/ZENODO.4423971.

Romanowska, I., Brughmans, T., Lichtenberger, A., \& Raja, R. (2018). Urban networks seen through ceramics: formal modelling approaches to pottery distribution in Jerash. In S. M. Sindbæk \& R. Raja (Eds.), Urban network evolutions. Towards a high definition archaeology (pp. 131-137). Aarhus: Aarhus University Press.

Romanowska, I., Crabtree, S. A., Harris, K., \& Davies, B. (2019). Agent-based modeling for archaeologists: Part 1 of 3. Advances in Archaeological Practice, 7(2), 178-184. https://doi.org/10.1017/aap.2019.6.

Romanowska, I., Lichtenberger, A., \& Raja, R. (2021). Trends in ceramic assemblages from the Northwest Quarter of Gerasa/Jerash, Jordan. Journal of Archaeological Science: Reports, 36, 102778. https://doi. org/10.1016/j.jasrep.2020.102778.

Stott, D., Kristiansen, S. M., Lichtenberger, A., \& Raja, R. (2018). Mapping an ancient city with a century of remotely sensed data. Proceedings of the National Academy of Sciences, 115(24), E5450-E5458. https:// doi.org/10.1073/pnas.1721509115.

Talbert, R. J. A. (2000). Barrington atlas of the Greek and Roman world. Princeton: Princeton University Press.

Uscatescu, A. (1996). La Cerámica del Macellum de Gerasa (Ŷaraš, Jordania). Madrid: Ministerio de Educación y Cultura.

Uscatescu, A. (2019). Revisiting Jerash late antique fine wares: a material and visual cultural approach. In A. Lichtenberger \& R. Raja (Eds.), Byzantine and Umayyad Jerash reconsidered. Transitions, transformation, continuities (Jerash Papers 4) (pp. 7-114). Turnhout: Brepols publishers.

Uscatescu, A. (2020). Late antique ceramic imports in Gerasa: new light on the Macellum finds (with a special reference to the neighbouring region). In A. Lichtenberger \& R. Raja (Eds.), Hellenistic and Roman Gerasa. The archaeology and history of a Decapolis city. Jerash papers 5 (pp. 173-300). Turnhout: Brepols publishers. 
Van Oyen, A. (2016). Historicising material agency: from relations to relational constellations. Journal of Archaeological Method and Theory, 23(1), 354-378. https://doi.org/10.1007/s10816-015-9244-0.

Van Oyen, A. (2017). Agents and commodities: a response to Brughmans and Poblome (2016) on modelling the Roman economy. Antiquity, 91(359), 1356-1363. https://doi.org/10.15184/aqy.2017.138.

Publisher's Note Springer Nature remains neutral with regard to jurisdictional claims in published maps and institutional affiliations.

\section{Affiliations}

\section{Iza Romanowska ${ }^{1} \cdot$ Tom Brughmans ${ }^{2} \cdot$ Philip Bes $^{3} \cdot$ Simon Carrignon $^{4} \cdot$ Line Egelund $^{5} \cdot$ Achim Lichtenberger $^{6} \cdot$ Rubina Raja $^{5}$}

Iza Romanowska

iromanowska@aias.au.dk

1 Aarhus Institute of Advanced Studies, Aarhus University, Aarhus, Denmark

2 Centre for Urban Network Evolutions and Classical Studies, Aarhus University, Aarhus, Denmark

3 Independent Researcher, Roman pottery, Den Haag, The Netherlands

4 CASE, Barcelona Supercomputing Centre, Barcelona, Spain

5 Centre for Urban Network Evolutions and Classical Studies, Aarhus University, Aarhus, Denmark

6 Institut für Klassische Archäologie und Christliche Archäologie, Westfälische Wilhelms Universität Münster, Münster, Germany 